\title{
An Evaluation of Groundnut Processing by Women in a Rural Area of North Central Nigeria
}

\author{
Hussaini Yusuf Ibrahim (Corresponding author) \\ Department of Agricultural Economics and Extension \\ Faculty of Agriculture Nasarawa State University Keffi, Nigeria \\ E-mail: Hussein464@yahoo.com \\ Napoleon D. Saingbe \\ College of Agriculture Lafia Nasarawa State, Nigeria \\ Hassan Ishaq Ibrahim \\ Department of Agricultural Economics and Extension, Faculty of Agriculture \\ Nasarawa State University Keffi, Nigeria \\ E- mail: Hassibrahim@yahoo.com
}

\begin{abstract}
This study evaluated the economic empowerment potentials of groundnut processing by women in rural areas of North central Nigeria state using a sample of 100 women processors randomly selected from the study area. Data analysis was done using Descriptive statistics, Net Farm Income Model and Data Envelopment Analysis (D.E.A). An average net returns of N10, 586.6 was obtainable within a processing cycle. The average pure technical and scale efficiency scores were 80 and 83 percent respectively. The major constraints confronting the processing of groundnut include inadequate capital for expansion and lack of processing machines. A significant opportunity exists for empowering rural women through groundnut processing.
\end{abstract}

Keywords: Groundnut, Processing, Women, Technical efficiency, Scale efficiency

\section{Introduction}

Groundnut (Arachis hypogea L.) otherwise called peanut, monkey nut, gobber pea and arachide belongs to the family leguminosea. It originated from Latin America and the Portuguese who were responsible for its introduction into West Africa from Brazil in the $16^{\text {th }}$ Century (Gibbon and Pain, 1985; Abalu and Etuk, 1986). Peanut is one of the most popular commercial crops in Nigeria. Nigeria produces $41 \%$ of the total groundnut production in West Africa (Echekwu and Emeka, 2005). It is cultivated for its kernels, the oil and hay for livestock. Groundnut cake is often deep fired or dried to make a snack locally called kuli-kuli. Groundnut flour is used as an ingredient in soups, sweet, confectionaries and puddings. Groundnut especially those produced in developing countries has been used traditionally since the origin of humanity. It is rich in oil and protein and has a high energy value.

Developing countries account for nearly 95 percent of world production (Echekwu and Emeka, 2005). Asia accounts for about $70 \%$ of this amount while the major producers, India and China together represent over two-thirds of global output. Other important producers of groundnut are: Nigeria, Senegal, Sudan and Argentina. Groundnut with $25 \%$ protein and more than $40 \%$ oil, is an important food crop in many areas of semi-arid tropics (Food and Agriculture Organisation, 1994).

In Nigeria, the processing of groundnut into various products is mostly done by women either for home consumption or for commercial purposes (Ibrahim et al., 2005). The most common commercial products of groundnut are: groundnut oil, groundnut cake and fried peanuts which are sold at market places or hawked on the streets, (Ihekoronye and Ngoddy, 1985). The processing of groundnut is both the source of income and employment to a large proportion of rural women in northern Nigeria. Thus, the achievement of the Millennium Development Goal number three (promotion of gender equality and women empowerment) in northern Nigeria, requires that a study be conducted to assess the economic 
empowerment potentials of this very important economic activity. In addition, the technical and scale efficiency in groundnut processing were also determined alongside the constraints affecting the processing of groundnut by rural women.

\section{Issues in literature on Data Envelopment Analysis}

Data Envelopment Analysis (DEA) is a non-parametric, linear programming based frontier analysis method that was originally developed to analyze the performance of organizations whose goals are not limited to profit maximization (Charnes et al., 1978). Data Envelopment Analysis (DEA) uses a non-parametric non stochastic piecewise linear production frontier in estimating technical efficiency. The DEA frontier estimates efficiency relative to the Pareto-efficient frontier which estimates best performance. Furthermore, it can obtain target values based on the best practices units (peers) for each inefficient firm that can be used to provide guidelines for improved performance (Abdulwadud, 2000).

The technique (DEA) is flexible in that it does not require specification of an underlying production relationship between inputs and outputs. It is able to incorporate inputs and outputs that are measured in different units and at different scales, and can accommodate multiple inputs and multiple outputs with minimal value judgments placed on the relative "worth" or "cost" of these inputs and outputs (Frija et al., 2008). According to Diaz et al (2004), a DEA model may be either input-oriented or output-oriented. As such, in deciding on the orientation of a DEA model one should also consider over which variables decision making units (DMUs) have most control (a sample of producers are referred to as decision making units (DMU) in DEA terminology). If DMUs have more control over output variables than input variables, the DEA model should be output-oriented; otherwise, the model should be input-oriented.

Furthermore, both output-oriented and input-oriented DEA models produce the same technical efficiency estimate for a farm under the assumption of constant returns to scale in production (Lovell, 1993). Under the assumption of variable returns to scale, the estimates of technical efficiency will differ. However, Coelli (1995) claims that since linear programming does not suffer from statistical problems such as simultaneous equation bias, the choice of a measure does not affect the efficiency estimates significantly.

Since none of the production frontier models used in empirical analyses of production efficiency is without its limitations, it is very important to make a careful choice of model. Coelli (1995) identified some weaknesses of the technique as follows.

(1) Since DEA is an extreme point technique, noise (even symmetrical noise with zero mean) such as measurement error can cause significant problems.

(2) A standard formulation of DEA creates a separate linear program for each DMU, thus large problems can be computationally intensive.

(3) DEA is good at estimating "relative" efficiency of a DMU but it converges very slowly to "absolute" efficiency. In other words, it can tell you how well you are doing compared to your peers but not compared to a "theoretical maximum."

(4) The main criticism of deterministic frontiers is that they rule out the possibility of a deviation from the frontier being caused by measurement error or other noise (such as bad weather). Therefore, any deviations from the estimated frontier are attributed to inefficiency.

Econometric stochastic production frontiers, however, obviate these criticisms. Furthermore, they provide a measure of the reliability of the technical efficiency estimates by means of the standard errors of the model parameters. However, this benefit comes at the cost of imposing assumptions about the functional form of the production technology and the distribution of the inefficiency term. These assumptions affect the analysis and distort efficiency scores (Fraser and Cordina, 1999). Avoiding such assumptions is an advantage of the DEA approach (Jafarullah and Premachandra, 2003). The minimum assumption DEA requires is the monotonicity and convexity of the efficient frontier (Abdulwadud, 2000).

The major weakness of DEA relates to its inability to account for measurement error (Kalyan, 2002). However, Banker (1996) and Fare and Grosskopf (1995) proposed several statistical tests which have subsequently made DEA a powerful tool for efficiency analysis Despite its limitations, DEA is surely a competitor with the stochastic production frontier in efficiency analysis. Several researchers such as Dalton (2004), Reig-Martinez and Picazo-Tadeo (2004), Abdulwadud (2000), Ogunyinka et al (2004) and Helfand (2003) have used DEA for estimating technical efficiency in agriculture.

\section{Materials and methods}

The study was conducted in five rural areas spread across the north central zone Nigeria. The locations are largely agrarian with the majority of the people as subsistence farmers who cultivate crops such as groundnut, yam, maize, sesame, cassava, cowpea, millet, and sorghum. Twenty women groundnut processors were randomly selected from each location to give a total of 100 respondents for the study. Data was collected with the aid of an interview schedule. Data 
was collected on the socio-economic characteristics of groundnut processors as well as input such as; raw groundnut, capital, machines, labour, and the outputs. The data collected were analyzed using simple descriptive statistics, Net farm income model and Data Envelopment Analysis. The Net farm income model is expressed as:

$\mathrm{NFI}=\mathrm{TR}(\mathrm{Qc} \times \mathrm{Pc}+\mathrm{Q}$ x Pou $)-\mathrm{TC}(\mathrm{TVC}+\mathrm{TFC})$

Where: $-\mathrm{NFI}=$ Net farm income

$\mathrm{TR}=$ Total revenue (from cake and oil)

$\mathrm{Qc}=$ Quantity of cake

$\mathrm{Pc}=$ Price of cake

Qo $=$ Quantity of oil

Pou $=$ Price of oil per unit

$\mathrm{TC}=$ Total cost

$\mathrm{TVC}=$ Total Variable cost

$\mathrm{TFC}=$ Total fixed cost

The variable cost items considered include capital (cost of transportation, firewood, and packaging), labour, cost of grinding, water, salt and raw groundnut. The fixed cost items include; drums, basin, processing machine, frying pan and mortar.

\subsection{Data Envelopment Analysis (DEA)}

Data Envelopment Analysis is a non-parametric, linear programming based frontier analysis method that was originally developed to analyze the performance of organizations whose goals are not limited to profit maximization (Charnes et al., 1978). Data Envelopment Analysis (DEA) uses a non-parametric non stochastic piecewise linear production frontier in estimating technical efficiency. The DEA frontier estimates efficiency relative to the pareto-efficiency frontier which estimates best performance. An output-oriented variable returns to scale DEA model was used to calculate technical, and scale efficiency in groundnut processing. The output oriented model estimates the proportional increase in outputs as inputs remains the unchanged. Assuming that there is data available on $\mathrm{K}$ inputs and $\mathrm{M}$ outputs in each of the $\mathrm{N}$ decision making units (i.e. processing) and input and output vectors are represented by the vectors $\mathrm{x}$ and $\mathrm{y}$, respectively for the ith processor. The data for all processors may be denoted by the $\mathrm{K} \mathrm{N}$ input matrix $(\mathrm{X})$ and $\mathrm{M} \mathrm{N}$ output matrix (Y). The envelope form of input-oriented VRS DEA model which is the most widely used is then specified according to Coelli, et al (1998) and Sharma et al (1999) as follows: Min $\theta \lambda \theta$

$$
\begin{array}{ll}
\text { St } & -\mathrm{y}_{1}+\mathrm{Y} \lambda \geq 0 \\
& \theta \mathrm{x}_{1}-\mathrm{X} \lambda \geq 0 \\
& \text { NI' } \lambda=1 \\
& \lambda \geq 0
\end{array}
$$

Where $\lambda$ is scalar and is a $\mathrm{N} x 1$ vector of constraints, the value of $\theta$ obtained signifies the efficiency score for the ith DMU. It will satisfy $\theta \leq 1$ with a value of 1 indicating a point on the frontier hence a technically efficient DMU according to Farrell (1957) definition. Thus, the linear programming problem needs to be solved $\mathrm{N}$ times and a value of $\theta$ is provided for each the processor (DMU) in the sample. Both CRS and the VRS DEA are conducted on the same data set and the ratio between the CRS and the VRS technical efficiency scores (CRS ${ }^{\text {T.E }} / \mathrm{VRS}^{\mathrm{T} . \mathrm{E}}$ ) is called scale efficiency (Latruffe et al, 2005). Efficiency scores in the study were estimated using the computer program, DEAP version 2.1 described in Coelli (1996). The inputs considered include: Raw groundnut (kg), Water (litres), Labour (man/days), Salt (g), Capital (firewood, packaging and transportation). The outputs considered include: Oil (litres) and Cake (kg).

\section{Results and Discussion}

\subsection{Inputs and outputs in groundnut processing}

The result shows inputs used and outputs obtained in groundnut processing. The inputs used include raw groundnut, water, salt and firewood. Others include fuel (kerosene) and labour. In a processing cycle of about 4 days, the total quantity of groundnut processed was $3862.80 \mathrm{~kg}$ with an average of $154.5120 \mathrm{~kg}$. The total quantity of water used was 1160.00 litres with an average of 46.400 litres per processor while the total quantity of fuel (kerosene) used was 44.00 litres. Furthermore, Table 1 shows the total of groundnut cake obtained was $2236.80 \mathrm{~kg}$ with an average of $89.4720 \mathrm{~kg}$ per processor while the total quantity of groundnut oil obtained was 1520.00 litres with an average of 60.800 litres.

\subsection{Costs and returns analysis in groundnut processing}

The result for the cost and returns analysis is presented in Table 2. The average total cost of processing was N20,250.9, 
which was dominated by the variable cost of processing which accounted for $90.7 \%$ of the average total cost. The fixed cost component on the other hand accounts for $9.3 \%$ of the average total cost of processing. The cost of raw groundnut dominated the variable cost by accounting for 79.59 of the total variable cost.

In terms of returns, an average gross returns of $\mathbf{N 3 0 , 8 1 7 . 6}$ per processing cycle was obtained from groundnut processing. The average gross returns was dominated by the return from groundnut oil which accounted for $56.3 \%$ of the average gross returns while the groundnut cake (kuli-kuli) accounts for $43.7 \%$ of the average gross returns. The revenue from groundnut oil also accounts for $85.5 \%$ of the total average cost of processing. This implies that for the processors to make sufficient profit, they have to sell both groundnut cake and groundnut oil. A similar finding was made by Hamidu, et al (2007). The result further shows that the average net return of N10,586.6 per processing cycle of about four days was obtained in groundnut processing by rural women in the study area. This means that in a month, net revenue of about N74106.20 was obtainable.

\subsection{Pure Technical Efficiency in Groundnut Processing}

An improvement in technical efficiency is essential for enhancing the profitability of any enterprise. An assessment of the level of technical efficiency in groundnut processing was done to provide further insights into the nature and causes of inefficiency in groundnut processing. The technical efficiency in groundnut processing in the study area varies from $0.07 \%$ for the 'least' practice processors and $100 \%$ for the 'best' practice processors with a mean value of 0.802 . Thus, in the short run, there is scope for increasing the outputs of groundnut oil/cake by about 20 percent through improvement in technical efficiency.

\subsection{Scale Efficiency in Groundnut Processing}

The scale Efficiency in groundnut processing in the study area varies from $12.4 \%$ to $100 \%$ with a mean of $83 \%$. This implies that, the groundnut processors in the study area need to increase their scale of operation by $17 \%$ to attain full scale efficiency. If the average scale efficiency score is less than the average pure technical efficiency score, then scale inefficiency is the cause of overall inefficiency (Krasachat, 2003). Otherwise, it is attributed to inefficient management practices (Latruffe et al., 2005). Hence, the low average pure technical efficiency (80 percent) in comparison to the average scale efficiency ( 83 percent) as shown in Table 3 and 4 respectively. Implies that pure Technical Efficiency in the cause of overall inefficiency. This implies that inefficiency in groundnut processing is due to managerial factors and not the scale of operation.

\subsection{The constraints faced by rural women in groundnut processing}

The constraints militating against groundnut processing in the study area varies from one respondent to another. However, ten constraints were identified as shown in Table 5. The processors pointed out that inadequate capital for expansion, unstable price of inputs and inadequate processing machines are the three major constraints hindering the processing of groundnut. A similar finding was also made by Haruna et al., 2006). The respondents also pointed out that their profit will increase if the constraints can be overcome.

\section{Conclusion}

Inefficiency in groundnut processing is due to managerial factors and not the scale of operation. Furthermore, a significant opportunity exists for empowering rural women and alleviating poverty in north central Nigeria through groundnut processing. This opportunity can be exploited through improvement in managerial ability and provision of advisory services.

\section{References}

Abalu, G.O.I and Etuk, E.G. (1986). Traditional versus improved groundnut production Practices Some further evidence from Northern Nigeria. Experimental Agriculture, 22, 33-38.

Abdulwadud, M. (2000). A Nonparametric analysis of technical efficiency of farms in bangladesh. Applied Economics, 32, 1665-1673.

Banker R.D. (1996). Hypothesis tests using data envelopment analysis. Journal of Productivity Analysis, 7,139-159.

Charnes, A., Cooper, W.W. and Rhodes, E. (1978). Measuring the efficiency of decision making units. European Journal of Operation Research, 2, 429-444

Coelli, T.J. (1995). Estimator and hypothesis tests for a stochastic frontier function: A Monte Carlo analysis' Journal of Productivity Analysis, 6, 3, 247-268.

Coelli, T.J. (1996). A guide to DEAP Version 2.1 A Data Envelopment Analysis (Computer) Program.CEPA Working Paper 96/08, Department of Econometrics, University of New England, Armidale

Coelli, T.J., Rao, D. S. and Battese, G. E. (1998). An introduction to efficiency and productivity analysis, Kluver Academic Publishers, Norwell, MC 
Dalton, T.J. (2004). Indivisible and spatial components of dairy firm inefficiency. Selected paper prepared for presentation at the American agricultural annual meeting, Denver, Colorado, August 1-4.

Diaz, R.J.A., Poyato, C. E. and Luque, L. R. (2004). Applying benchmarking and data envelopment analysis (DEA) techniques to irrigation district in Spain. Irrigation and Drainage, 53, 135-143.

Echekwu, C.A and Emeka, I. (2005). Groundnut, endowing, the groundnut/rediscovery programme in Nigeria. Opah mission Abuja pp 18

Färe, R. and Grosskopf, S. (1995). Productivity and quality changes in swedish pharmacies International Journal of Production Economics, 39, 1 \& 2, 137-147

Farrell, M.J. (1957). The measurement of productive efficiency. Journal of the Royal Statistical Society, A120, 253 290.

Food and Agricultural Organisation. (1994). General conclusions and recommendations of expert consultation on fats and oils in Human nutrition. F.A.O: Rome.

Fraser, I. and Cordina, D. (1999). An Application of data envelopment analysis to irrigated dairy farms in northern victoria, Australia paper presented to the 43rd annual conference of the Australian Agricultural and Resource Economics Society, Christchurch, January 20-22.

Frija, A., Speelman, S., Chebil, A., Buysse, J. and Van Huy, G. (2008). Performances and efficiencies of the irrigation water users' associations in Tunisia. Paper presented at the 107th EAAE Seminar "Modelling of Agricultural and Rural Development Policies". Sevilla, Spain, January 29th -February 1st, 2008.

Gibbon, D and Pain, A. (1985). Crops of the drier region of the tropics. longman group Ltd UK pp 146

Hamidu, B.M., Kuli, S.G. and Mohammad, I. (2007). Profitability analysis of groundnut processing among women entrepreneurs in Bauchi metropolis. Management Network Journal, 3, 6, 389-395.

Haruna, U., Murtala, N.and Ahmed, H.S. (2006). Economics of groundnut processing among the rural women in Katagun local government area Bauchi state, Nigeria. Savannah Journal ofAagriculture, 1,2, 138-144.

Helfand, M.S. (2003) Farm size and the determinants of productive efficiency in the Brazilian center-west contributed paper selected for presentation at the 25th International Conference of Agricultural Economists, Durban, South Africa. August 16-22.

Ibrahim, D.B., Dutse, A.Y. and Hamidu, B.M. (2005). Assessment of awareness level of air and noise pollution of car transport among Motorist in Bauchi metropolis. Management Network Journal, 3, 6, $26-35$.

Ihekoronye, A.I. and Ngoddy, P.O (1985). Integrated, food science and technology for the Tropics. Macmillan Publishers Limited London pp 364.

Jafarullah,M and Premachandra, E. (2003). Sensitivity of technical efficiency estimates to estimation approaches: An investigation using New Zealand Dairy Industry Data. University of Otago Economics Discussion Papers, No. 0306

Kalyan, C. (2002). Cotton farmers' technical efficiency: stochastic and non stochastic production function approaches. Agricultural and Resource Economics Review, 12,3,:34-41.

Krasachat, W. (2003). Technical efficiencies of rice farms in Thailand: A non-parametric Approch. Paper presented to the Hawaii International Conference on Business, Honolulu, June 18-21

Latruffe, L., Balcombe, K., Davidora, S., and Zawalinska, K. (2005). Technical and scale efficiency of crop and livestock farms in Poland: does specialization matter. Agricultural Economics, 32, 281-296.

Lovell, C.A.K. (1993). Production frontiers and productive efficiency, in Fried, H.O., Lovell, C.A.K and Schmidt, S.S. (Eds), The Measurement of productive efficiency: Techniques and Applications. Oxford University Press, New York.

Ogunyinka, E.O. Odeh, O.O and Ajibefun, I.A. (2004). Examining efficiency under multi-cropping systems. Selected paper prepared for presentation at the Southern Agricultural Economics Association Annual Meeting, Tulsa, Oklahoma, February $14-18$.

Reig-Martınez, E. and Picazo-Tadeo, A.J. (2004). Analysing farming systems with data envelopment analysis: The case of Citrus Farming in Spain Agricultural Systems, 3, 8, 21-26.

Sharma, K.R., Leung, P.S. and H.M. Zaleski. (1999). Technical, allocative and economic efficiency in swine production in Hawaii: A comparison of parametric and non parametric Approach. Agricultural Economics, 20, 1, 23-35. 
Table 1. Inputs and outputs in groundnut processing

\begin{tabular}{|l|l|l|l|l|}
\hline $\mathbf{N}$ & MINIMUM & MAXIMUM & TOTAL & MEAN \\
\hline Groundnut oil & 30.00 & 120.00 & 1520.00 & 60.8000 \\
\hline Groundnut cake & 37.60 & 112.80 & 2236.80 & 154.5120 \\
\hline Raw Groundnut & 90.00 & 180.00 & 3862.80 & 154.5120 \\
\hline Water & 20.00 & 80.00 & 1160.00 & 46.4000 \\
\hline Salt & 30 & 25 & 38.15 & 1.5260 \\
\hline Firewood (bundles) & 1.00 & 12.00 & 98.00 & 3.9200 \\
\hline Fuel (kerosene) & 0.00 & 20.00 & 44.00 & 1.7600 \\
\hline Labour & 0.38 & 1.20 & 21.03 & 0.8412 \\
\hline
\end{tabular}

Table 2. Cost and returns analysis from groundnut processing (US $\$=\mathbf{N}$ 153:00)

\begin{tabular}{|c|c|c|c|c|c|}
\hline COST/RETURNS COMPONENTS & UNIT & QUANTITY & $\begin{array}{l}\text { COST } \\
\text { PER } \\
\text { UNIT }\end{array}$ & $\operatorname{CosT}(\mathrm{N})$ & $\%$ \\
\hline A. VARIABLE COST & $\mathrm{N}$ & & & & \\
\hline i. Raw groundnut & $\mathrm{Kg}$ & 94.6 & 170 & 16,080 & $79.5 \%$ \\
\hline ii. Water & Litres & 45.6 & 1 & 45.6 & $0.2 \%$ \\
\hline iii. Salt & $\mathrm{Kg}$ & 1.5 & 50 & 78.0 & $0.4 \%$ \\
\hline iv. Firewood & Bundle & 3.5 & 200 & 712 & $3.5 \%$ \\
\hline v. Fuel (kerosene) & Litres & 0.83 & 200 & 166 & $0.8 \%$ \\
\hline vi. $\quad$ Labour & Manday & 1.2368 & 250 & 3092 & $1.5 \%$ \\
\hline $\begin{array}{l}\text { vii. Other cost (transport, extracting } \\
\text { oil, Grinding and marketing charges }\end{array}$ & $\mathrm{N}$ & - & - & 952.8 & $4.7 \%$ \\
\hline TOTAL VARIABLE COST & $\mathrm{N}$ & - & - & 18.363 .6 & $90.7 \%$ \\
\hline \multicolumn{6}{|l|}{ B. FIXED COST } \\
\hline Depreciation/Repair/maintenance & $\mathrm{N}$ & - & - & $1,887.3$ & 9.3 \\
\hline C. TOTAL COST (TVC+FC) & $\mathrm{N}$ & - & - & $20,250.9$ & $100 \%$ \\
\hline \multicolumn{6}{|l|}{ D. REVENUE: } \\
\hline i. Revenue from groundnut cake & $\mathrm{N}$ & 5.2 & 2,600 & 13.512 .8 & $43.8 \%$ \\
\hline ii. Revenue from groundnut oil & $\mathrm{N}$ & 2.8 & 6,200 & $17,304.8$ & $56.2 \%$ \\
\hline E. GROSS REVENUE $\left(\mathrm{D}_{\mathrm{i}}+\mathrm{D}_{\mathrm{ii}}\right)$ & $\mathrm{N}$ & & & $30,817.6$ & $100 \%$ \\
\hline F. NET RETURN (E-C) & $\mathrm{N}$ & & & $10,586.6$ & - \\
\hline
\end{tabular}


Table 3. Pure technical efficiency estimates in groundnut processing

\begin{tabular}{|l|l|l|}
\hline CLASS INTERVAL & FREQUENCY & PERCENTAGE (\%) \\
\hline $0.071-0.2568$ & 9 & $9 \%$ \\
\hline $0.2569-0.4426$ & 11 & $11 \%$ \\
\hline $0.4427-0.6284$ & 6 & $6 \%$ \\
\hline $0.6285-0.8142$ & 8 & $8 \%$ \\
\hline $0.8143-1.0$ & 66 & $66 \%$ \\
\hline Total & $\Sigma \mathrm{F}=100$ & $100 \%$ \\
\hline $\begin{array}{l}\text { Minimum Technical Efficiency }=0.071 \\
\text { Maximum Technical Efficiency }=1.0 \\
\text { Mean }=0.802\end{array}$ & \\
\hline
\end{tabular}

Table 4. Scale efficiency estimates in groundnut processing

\begin{tabular}{|l|l|l|}
\hline CLASS INTERVAL & FREQUENCY & PERCENTAGE (\%) \\
\hline $0.124-0.2992$ & 8 & $8 . \%$ \\
\hline $0.2993-04744$ & 10 & $10 \%$ \\
\hline $0.4745-0.6496$ & 1 & $1 \%$ \\
\hline $0.6497-0.8248$ & 14 & $14 \%$ \\
\hline $0.8249-1.0$ & 67 & $67 \%$ \\
\hline Total & $\Sigma \mathrm{F}=100$ & $100 \%$ \\
\hline $\begin{array}{l}\text { Minimum scale Efficiency }=0.124 \\
\text { Maximum Scale Efficiency }=1.0 \mathrm{i} \\
\text { Mean }=0.827\end{array}$ \\
\hline
\end{tabular}

Table 5. Constraints faced by women groundnut processors

\begin{tabular}{|l|l|l|l|}
\hline CONSTRAINTS & FREQUENCY & PERCENTAGE & RANKING \\
\hline In adequate labour supply & 08 & 2.1 .0 & 10 \\
\hline Inadequate capital for expansion & 77 & 21.0 & 1 \\
\hline Unstable price of inputs & 74 & 20.0 & 2 \\
\hline Unstable price of outputs & 27 & 7.2 & 6 \\
\hline Lack of readily available market & 16 & 4.3 & 7 \\
\hline Incomplete return of credit sales & 13 & 3.4 & 8 \\
\hline Low volume of production & 49 & 13.0 & 4 \\
\hline Inadequate Processing machines & 60 & 16.0 & 3 \\
\hline Unstable Electricity & 11 & 3.0 & 9 \\
\hline Lack of processing shed & 38 & 10.0 & 5 \\
\hline TOTAL & $\mathbf{3 7 3}$ & $\mathbf{1 0 0}$ & \\
\hline
\end{tabular}

*Multiple responses allowed. 